Zeszyty Naukowe Szkoły Głównej Gospodarstwa Wiejskiego w Warszawie Problemy Rolnictwa Światowego tom 17 (XXXII), zeszyt 3, 2017: 81-92

DOI: $10.22630 /$ PRS.2017.17.3.55

Anna Górska ${ }^{1}$, Monika Krawiec ${ }^{2}$

Szkoła Główna Gospodarstwa Wiejskiego w Warszawie

\title{
Analiza efektywności informacyjnej w formie słabej na rynkach „soft commodities" z wykorzystaniem wybranych testów statystycznych
}

\section{The Analysis of Weak-form Efficiency on the Markets of Soft Commodities with the Use of some Statistical Tests}

\begin{abstract}
Synopsis. Hipoteza rynków efektywnych stała się przedmiotem zainteresowania naukowców pod koniec lat 70. XX wieku. Poczatkowo badania w tym zakresie koncentrowały się na rynkach akcji, lecz później zainteresowanie badaczy przeniosło się na rynki towarowe, przede wszystkim rynek ropy i rynek produktów rolnych, głównie zbóż. Efektywność rynków „soft commodities” także była przedmiotem badań, lecz w mniejszym stopniu, ponieważ większość z nich koncentrowała się na pojedynczych produktach. Stąd celem niniejszej pracy jest rozszerzenie badań i weryfikacja słabej formy efektywności dla sześciu towarów z grupy „soft commodities”: kawy, kakao, cukru, bawełny, mrożonego koncentratu soku pomarańczowego i kauczuku. Materiał empiryczny stanowią dzienne notowania tych towarów w latach 2007 - 2016. Po oszacowaniu logarytmicznych stóp zwrotu, przeprowadzono następujące testy statystyczne: test serii, test autokorelacji, testy Boxa-Pierce'a i BoxaLjunga. Otrzymane wyniki nie są jednoznaczne, co otwiera pole do dalszych badań z wykorzystaniem alternatywnej metodologii.
\end{abstract}

Slowa kluczowe: soft commodities, efektywność informacyjna w formie słabej, testy statystyczne

\begin{abstract}
The Efficient Market Hypothesis received much attention in the late 1970s. Those early studies focused on examining the efficiency of stock markets, however since that time the researchers' interest has shifted to commodity markets. The studies usually focus on the markets of oil and of agricultural products, mainly grains. The efficiency of soft commodities market is also examined but not to the same extent. Majority of investigations focus on single products of this category. Thus the aim of our paper is to extend the research and to analyze the weak-form efficiency of six soft commodities: coffee, cocoa, sugar, cotton, frozen concentrated orange juice and rubber. Data under consideration covers daily spot prices of the commodities in the period 2007-2016. Having calculated their logarithmic returns we perform the following statistical tests: runs test, autocorrelation test, BoxPierce and Box -Ljung tests. As the results obtained are not homogenous, this opens a door to further investigations with the use of different methodology.
\end{abstract}

Key words: soft commodities, weak-form of informational efficiency, statistical tests

\section{Wstęp}

Rynek towarowy jest drugim (obok rynku finansowego) rynkiem, którego funkcjonowanie ma fundamentalne znaczenie dla każdej gospodarki. Od wielu lat rynki towarowe coraz bardziej upodabniają się do rynków finansowych i następuje proces

\footnotetext{
${ }^{1}$ dr, Wydział Nauk Ekonomicznych, ul. Nowoursynowska 166,02-787 Warszawa, e-mail: anna_gorska@sggw.pl ${ }^{2}$ dr, Wydział Zastosowań Informatyki i Matematyki, ul. Nowoursynowska 159, 02-776 Warszawa, e-mail: krawiec.monika@gmail.com
} 
określany mianem „ufinansowienia” rynków towarowych ${ }^{3}$. W efekcie, nie tylko producenci i konsumenci towarów, ale także inwestorzy finansowi (zarówno instytucjonalni, jak i indywidualni) są zainteresowani rozpoznaniem trendów i prawidłowości, a także anomalii w funkcjonowaniu rynków towarowych. Jednym z zagadnień, które od lat jest przedmiotem badań naukowców, jest problem informacyjnej efektywności rynku. Początkowo badania w tym zakresie koncentrowały się na rynkach kapitałowych. Natomiast już od lat osiemdziesiątych XX wieku rozpoczęto badania efektywności informacyjnej rynków towarowych, przede wszystkim rynku ropy (Gjolberg, 1985; Panas, 1991; Alvarez-Ramirez i in., 2008; Charles i Darné, 2009; Zahng i in., 2014; Górska i Krawiec, 2016) oraz rynku produktów rolnych, takich jak pszenica, kukurydza i soja (Bigman i in., 1983; Canarella i Pollard, 1985; Aulton i in., 1997; McKenzie i Holt, 2002; Wang i Ke, 2005; Ali i Gupta, 2011; Kristoufek i Vosvrda, 2014). Badania efektywności rynku towarów z grupy określanej mianem „soft commodities" pojedynczych towarów (Gordon, 1985; Sabuhoro i Larue, 1997; Lokare, 2007; Borowski, 2015a, 2015b). Stąd celem niniejszej pracy jest rozszerzenie dotychczasowych analiz i przeprowadzenie badania informacyjnej efektywności w formie słabej dla rynków sześciu najważniejszych towarów, zaliczanych do tzw. "softs", to jest: kawy, kakao, cukru, bawełny, mrożonego koncentratu soku pomarańczowego i kauczuku (Fabozzi i in., (2008) włączają do tej grupy jeszcze jedwab, wełnę i drewno).

\section{Materiał empiryczny}

Materiał empiryczny stanowią dzienne ceny spot na zamknięcie w okresie 2007-2016 następujących towarów: kawa, kakao, cukier, bawełna, mrożony koncentrat soku pomarańczowego, kauczuk (dane udostępniono na stronie internetowej serwisu Bloomberg: www.bloomberg.com). Na rysunku 1 przedstawiono te szeregi czasowe. W badanym okresie notowania kawy osiągnęły maksymalny poziom (304,9 USD/funt) w dniu 3 maja 2011 r., zaś minimalny (101,35 USD/funt) w dniu 3 maja 2007 r. Najwyższą cenę kakao (2413 GBP/tonę) odnotowano 15 lipca 2010 r., a najniższą (868 GBP/tonę) 26 stycznia 2007 r. Ceny cukru osiągnęły maksimum (35,31 USD/funt) 2 lutego $2011 \mathrm{r}$., a minimum 8,45 USD/funt 13 czerwca 2007 r. Notowania bawełny osiągnęły najwyższy poziom $(215,15$ USD/funt) 4 marca 2011 r., a najniższy (39,14 USD/funt) 11 listopada 2008 r. Mrożony koncentrat soku pomarańczowego był najdroższy w dniu 1 listopada $2016 \mathrm{r}$. (cena na poziomie 232,85 USD/tonę), a najtańszy - 18 lutego 2009 r. (cena na poziomie 66,25 USD/tonę). Najwyższą cenę kauczuku (575 JPY/kg) zaobserwowano dnia 14 lutego 2011 r., najniższą (102 JPY/kg) -12 grudnia $2008 \mathrm{r}$.

\footnotetext{
${ }^{3}$ Zawojska (2011) używa terminu „finansjeryzacja”, zaś Tomaszewski (2013) terminu „finansjalizacja” rynków towarowych.

${ }^{4}$ Najszersza definicja ,,soft commodities” zalicza do nich wszelkie towary pochodzenia roślinnego, takie jak zboża, używki, owoce, rośliny oleiste itp. Jednak, ze względu na szczególne znaczenie gospodarcze, zboża są często wyróżniane jako osobna kategoria towarów i wówczas, tak zawężoną, kategorię „,soft commodities” określa się mianem towarów roślinnych pochodzenia tropikalnego z uwagi na geograficzne pochodzenie towarów należących do tej grupy (Tomaszewski, 2013).
} 


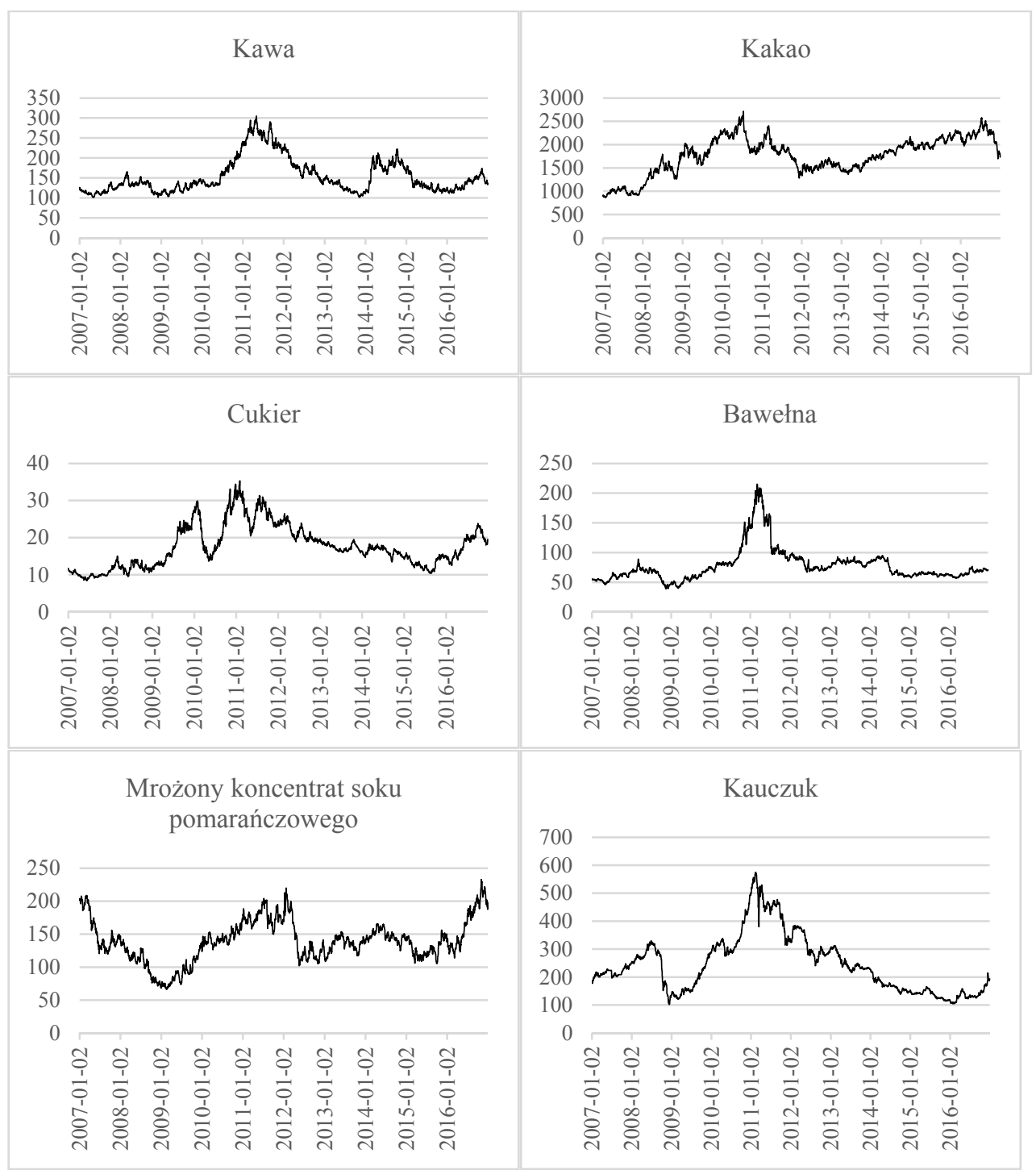

Rys. 1. Ceny spot na zamknięcie towarów z grupy „soft commodities” w okresie 2007-2016 Fig.1. Soft commodities closing spot prices in the period 2007-2016

Źródło: opracowanie własne.

Na bazie notowań, których kształtowanie się przedstawiono na rysunku 1, oszacowano logarytmiczne stopy zwrotu, na podstawie których wyznaczono najważniejsze charakterystyki analizowanych szeregów czasowych, to jest średnią, odchylenie standardowe, współczynnik kurtozy, asymetrii, maksymalne i minimalne poziomy stóp zwrotu oraz wartości statystyki Jarque'a-Bery (JB). Zestawiono je w tabeli 1. Na tej podstawie można zauważyć, że tylko dla jednego z analizowanych towarów - dla mrożonego 
koncentratu soku pomarańczowego otrzymano ujemną oczekiwaną stopę zwrotu (średnią). Pozostałe towary wygenerowały dodatnie oczekiwane stopy zwrotu (najwyższą - kakao). Większość towarów charakteryzuje ujemna asymetria rozkładu stóp zwrotu (wyjątek stanowi kawa) oraz podwyższona kurtoza (z wyjątkiem stóp zwrotu kawy i mrożonego koncentratu soku pomarańczowego). Ponadto, wartości statystyki Jarque’a-Bery wskazują na odrzucenie hipotezy o normalności rozkładu stóp zwrotu wszystkich analizowanych towarów.

Tabela 1. Podstawowe charakterystyki stóp zwrotu towarów z grupy „soft commodities”

Table 1. Basic characteristics for logarithmic returns of soft commodities

\begin{tabular}{|c|c|c|c|c|c|c|}
\hline \multirow[b]{2}{*}{ Charakterystyka } & \multicolumn{6}{|c|}{ Towar } \\
\hline & Kawa & Kakao & Cukier & Bawełna & $\begin{array}{l}\text { Mrożony koncentrat } \\
\text { soku } \\
\text { pomarańczowego }\end{array}$ & Kauczuk \\
\hline Liczba obserwacji & 2609 & 2609 & 2609 & 2609 & 2609 & 2609 \\
\hline Średnia & 0,00003 & 0,00026 & 0,00019 & 0,00009 & $-0,00001$ & 0,00002 \\
\hline Odchylenie standardowe & 0,01982 & 0,01550 & 0,02190 & 0,01888 & 0,02163 & 0,01711 \\
\hline Kurtoza & 2,08055 & 3,48264 & 3,26530 & 4,47554 & 2,74104 & 8,78294 \\
\hline Skośność & 0,09118 & $-0,14439$ & $-0,07872$ & $-0,31238$ & $-0,13873$ & $-0,67168$ \\
\hline Minimum & $-0,11089$ & $-0,10401$ & $-0,12366$ & $-0,15555$ & $-0,12314$ & $-0,14774$ \\
\hline Maksimum & 0,11789 & 0,07810 & 0,13062 & 0,10527 & 0,11474 & 0,11879 \\
\hline JB & 471,33 & 1320,77 & 1155,69 & 2209,30 & 820,62 & 8544,24 \\
\hline
\end{tabular}

Źródło: obliczenia własne.

\section{Metodologia badania}

Hipoteza efektywnych (informacyjnie) rynków kapitałowych została sformułowana przez E. Famę (1970). Zdefiniował on efektywny rynek kapitałowy jako taki, na którym ceny zawsze w pełni odzwierciedlają dostępne informacje. Obecnie efektywność rynku kapitałowego rozumiana jest jako natychmiastowe i prawidłowe odzwierciedlanie w cenach ściśle określonego typu informacji. Można więc stwierdzić, że przedmiotem rozważań jest efektywność względem pewnego rodzaju (zbioru) informacji, a nie efektywność absolutna. W tym ujęciu rynek jest efektywny, jeżeli na podstawie informacji danego typu nie można systematycznie osiągać ponadprzeciętnych (ponadnormalnych) stóp zwrotu. Do przyjęcia takiej definicji niezbędne jest określenie pojęcia „normalnych” stóp zwrotu. Zazwyczaj rozumie się przez nie stopy zwrotu wynikające ze stosowanego modelu rynku kapitałowego, na przykład CAPM (Capital Asset Pricing Model) lub APT (Arbitrage Pricing Theory).

Podstawowe typy informacji, względem których bada się efektywność rynku kapitałowego, to:

- historyczne notowania papierów wartościowych,

- wszelkie publicznie dostępne informacje,

- wszelkie informacje, a więc te dostępne publicznie, jak i poufne (dostępne wyłącznie dla wybranych inwestorów).

Analizując efektywność rynku kapitałowego względem informacji z wymienionych zakresów mówi się o trzech stopniach (formach) efektywności. Są to: słaba, półsilna i silna 
efektywność. W związku z tym, że odrzucenie hipotezy dotyczącej występowania efektywności w formie słabej implikuje brak efektywności w formie półsilnej i silnej (Algieri, Kalkhul, 2014), w pracy koncentrujemy się na weryfikacji efektywności w formie słabej.

Do badania efektywności w formie słabej wykorzystuje się narzędzia analizy technicznej oraz testy statystyczne, weryfikujące losowość zmian w szeregu. Są to zarówno testy parametryczne, jak i nieparametryczne. Według Osińskiej (2006) weryfikacja może polegać na:

1) ocenie, czy ceny instrumentów finansowych są dobrze opisane przez proces błądzenia przypadkowego:

$$
p_{t}=p_{t-1}+e_{t},
$$

gdzie $p_{t}$ to logarytmy cen, zaś przez $e_{t}$ rozumie się czynniki nieznane badaczowi np. nowe informacje;

2) ocenie, czy stopy zwrotu $\mathrm{z}$ inwestycji w instrumenty finansowe mają własności białego szumu:

$$
R_{t}=e_{t}
$$

Celem badań jest wyjaśnienie, czy model (1) jest dobrym przybliżeniem dla analizowanych cen aktywów oraz czy można stwierdzić, że równanie (1) w którym $e_{t}$ są niezależnymi zmiennymi losowymi o takim samym rozkładzie (ze skończoną wariancją), jest modelem dobrze dopasowanym do tych kursów cen.

Wśród testów, pozwalających na sprawdzenie, czy dany szereg jest szeregiem błądzenia przypadkowego, można wskazać m.in.: testy obecności pierwiastków jednostkowych, testy współczynników autokorelacji, test ilorazów wariancji, test serii, test znaków, badanie zależności i korelacji długookresowych, tzw. analizę R/S, badanie występowania efektów kalendarzowych (Witkowska i in., 2008).

Test serii, należący do grupy testów nieparametrycznych, nazywanych również testami zgodności, ma następującą ideę. Seria na rynku towarowym jest definiowana jako nieprzerwany ciąg zmian cen towarów w tym samym kierunku (tzn. wzrostów lub spadków cen) o dowolnej długości, przed i po którym następują zmiany w kierunku przeciwnym (Czekaj i in., 2001). W tym przypadku zostaną porównane frakcje serii z rozkładem, jakiemu podlegałyby dane, gdyby badany proces był błądzeniem losowym, a konkretnie białym szumem. Jeżeli zmiany cen mają charakter losowy, to prawdopodobieństwo, że po spadku ceny nastąpi dalszy spadek, powinno być równe prawdopodobieństwu wystąpienia wzrostu ceny. Oznaczałoby to, że w dużej próbie obserwacji należy oczekiwać wystąpienia podobnej liczby sekwencji, czyli następujących po sobie spadków lub wzrostów cen i liczby zmian znaków, następujących po wzroście spadków lub po spadkach wzrostów cen (Buczek, 2006). Modelując zachowanie cen towarów zakłada się występowanie serii wartości dodatnich, ujemnych oraz zer.

Aby przeprowadzić test serii, wprowadza się zmienną pomocniczą $R_{t}^{*}$, taką że:

$$
R_{t}^{*}=\left\{\begin{array}{ccc}
1, & \text { gdy } & R_{t}>0 \\
0, & \text { gdy } & R_{t}=0 \\
-1, & \text { gdy } & R_{t}<0
\end{array} .\right.
$$

W teście serii formułuje się następujące hipotezy: 
$\mathrm{H}_{0}: R_{t}^{*}$ jest białym szumem,

$\mathrm{H}_{1}: R_{t}^{*}$ nie jest białym szumem.

Do weryfikacji postawionej hipotezy wykorzystuje się statystykę $K$, która dla dużej liczby danych ma w przybliżeniu asymptotyczny rozkład normalny $\mathrm{N}(0,1)$ (Jajuga, 2000).

Statystyka $K$ określona jest wzorem:

$$
K=\frac{H-E(\widetilde{H})}{\sqrt{\operatorname{Var}(\widetilde{H})}},
$$

gdzie: $H$ jest warunkową realizacją zmiennej losowej $\widetilde{H}$ i oznacza całkowitą liczbę serii.

W celu przeprowadzenia tego testu wyróżnia się najpierw nieprzerwane serie dodatnich, zerowych i ujemnych stóp zwrotu $R_{t}^{*}$. Wprowadza się także zmienną pomocniczą $h_{t}$, taką że:

$$
h_{t}=\left\{\begin{array}{l}
0, \text { gdy } R_{t}^{*}=R_{t+1}^{*} \\
1, \text { gdy } R_{t}^{*} \neq R_{t+1}^{*}
\end{array} .\right.
$$

Jeżeli $h_{t}=1$, oznacza to że $R_{t+1}$ rozpoczyna nową serię. Całkowitą liczbę serii określamy za pomocą wzoru:

$$
H=1+\sum_{t=1}^{n-1} h_{t},
$$

gdzie: $n$ oznacza długość badanego szeregu złożonego ze stóp zwrotu.

Jeżeli badany szereg składa się $\mathrm{z} n_{l}$ dodatnich stóp zwrotu, $n_{2} \mathrm{o}$ wartościach zerowych i $n_{3}$ ujemnych stóp zwrotu, to wtedy średnią i wariancję zmiennej losowej $\widetilde{H}$ określamy wzorami (Papla, 2003 za Taylor, 1986):

$$
\begin{gathered}
E(\widetilde{H})=n+1-\frac{\sum_{j=1}^{3} n_{j}^{2}}{n}, \\
\operatorname{Var}(\widetilde{H})=\frac{\sum_{j=1}^{3} n_{j}^{2}\left(\sum_{j=1}^{3} n_{j}^{2}+n+n^{2}\right)-2 n \sum_{j=1}^{3} n_{j}^{3}-n^{2}}{n^{3}-n} .
\end{gathered}
$$

Przyjmujemy poziom istotności 0,05 . Jeśli statystyka $|K|>1,96$ to hipotezę zerową odrzucamy.

Testy niezależności przyrostów cen pozwalają na ustalenie niektórych cech badanych szeregów czasowych, w przypadku gdy założono, że są losowe. Test autokorelacji bada, czy dane w szeregach czasowych są ze sobą skorelowane, czy też nie. Natomiast testy Boxa Pierce'a (portmanteau) i Boxa - Ljunga (adjusted portmanteau) służą sprawdzeniu, czy zmiany cen są niezależnymi zmiennymi losowymi o jednakowych rozkładach.

Za pomocą testu autokorelacji weryfikujemy następującą hipotezę zerową:

$\mathrm{H}_{0}: \rho=0$ - stopy zwrotu cen towarów są ze sobą nieskorelowane

wobec

$\mathrm{H}_{1}: \rho \neq 0$ - stopy zwrotu są skorelowane. 
Do weryfikacji tej hipotezy wykorzystuje się współczynnik autokorelacji stóp zwrotu dany wzorem:

$$
\hat{\rho}(k)=\frac{\sum_{t=1}^{T-k}\left(R_{t}-\bar{R}_{T}\right)\left(R_{t+k}-\bar{R}_{T}\right)}{\sum_{t=1}^{T}\left(R_{t}-\bar{R}_{T}\right)^{2}},
$$

gdzie:

$\hat{\rho}(k)$ jest autokorelacją rzędu $k$,

$\bar{R}_{T}$ jest to średnia arytmetyczna stóp zwrotu,

$T$ jest liczbą obserwacji,

$R_{t}$ jest stopą zwrotu w chwili $t$,

$R_{t+k}$ jest stopą zwrotu cen oddalonych od siebie o $k$ chwil.

Przy założeniu prawdziwości $\mathrm{H}_{0}$, statystyka $S=\sqrt{T} \hat{\rho}(k)$ ma rozkład asymptotycznie normalny o parametrach $\mathrm{N}(0,1)$ (Papla, 2003 za Taylor, 1986). Na poziomie istotności 0,05 hipotezę zerową $\mathrm{H}_{0}$ odrzucamy, gdy wartość bezwzględna statystyki $S$ jest większa od 1,96.

Testy Boxa-Pierce'a (portmanteau) oraz Boxa-Ljunga (adjusted portmanteau) pozwalają na stwierdzenie, czy elementy badanych szeregów czasowych złożonych z cen towarów są niezależnymi zmiennymi losowymi. Celem tych testów jest weryfikacja następującej hipotezy zerowej:

$\mathrm{H}_{0}: \rho_{1}=\rho_{2}=\ldots=\rho_{m}=0$ (stopy zwrotu są nieskorelowane)

wobec

$\mathrm{H}_{1}: \rho_{i} \neq 0, i=\{1, \ldots, m\}$ (stopy zwrotu są ze sobą skorelowane).

Testy te badają istotność kolejnych współczynników korelacji. Statystyką testową jest statystyka $Q$ (Jajuga, 2000; Papla, 2003). W przypadku testu Boxa - Pierce'a przyjmuje ona postać:

$$
Q=T \sum_{k=1}^{m} \hat{\rho}(k)^{2},
$$

zaś w przypadku testu Boxa - Ljunga jest postaci:

$$
Q^{\prime}=T(T+2) \sum_{k=1}^{m} \frac{\hat{\rho}(k)^{2}}{T-k}
$$

gdzie: $\hat{\rho}(k)$ - współczynnik autokorelacji rzędu $k$, dla $k=1, \ldots, m$ (porównaj wzór 7), $T$ - długość szeregu czasowego, $m \approx \ln (T)$ - maksymalne opóźnienie.

Statystyki $Q$ oraz $Q$ ' mają rozkład chi - kwadrat o $m$ stopniach swobody. Ze wzorów (8) i (9) wynika, że liczba stopni swobody $m$ to liczba współczynników autokorelacji, które brane są pod uwagę podczas obliczania statystyki $Q$ lub $Q^{\prime}$. Jajuga (2000) twierdzi, że „dla zbyt małych $m$ można nie zauważyć znaczących autokorelacji wyższych rzędów, zaś dla $m$ zbyt dużych może zmniejszyć się moc testu ze względu na obecność nieznaczących autokorelacji wyższych rzędów".

W badaniach przeprowadzonych w niniejszej pracy przyjęto następujące wartości $m$ : 10, 20 i 30. Gdy wartość empiryczna statystyki $Q$ przekroczy wartość krytyczną rozkładu 
$\chi_{m}^{2}$, przy danym poziomie istotności, $\mathrm{H}_{0}$ można odrzucić. Na poziomie istotności 0,05 odrzuca się hipotezę, że stopy zwrotu cen są nieskorelowane, jeśli $Q_{10}>18,31, Q_{20}>31,41$, $Q_{30}>43,77$ (Jajuga, 2000).

\section{Wyniki badań empirycznych}

W pierwszym kroku prowadzonych badań, wykorzystując logarytmiczne stopy zwrotu sześciu analizowanych towarów z grupy „soft commodities”, wykonano test serii. Wyniki tego testu, to znaczy wartości statystyki $K$ (wzór 3), przedstawiono w tabeli 2.

Tabela 2. Wartości statystyki $K$ dla stóp zwrotu towarów z grupy „soft commodities”

Table 2. Values of $K$ statistics for logarithmic returns of soft commodities

\begin{tabular}{l|c}
\hline \multicolumn{1}{c|}{ Towar } & $\mathrm{K}$ \\
\hline Kawa & $\mathbf{2 , 7 2 0}$ \\
Kakao & $\mathbf{- 4 , 2 5 9}$ \\
Cukier & 0,459 \\
Bawełna & $-0,390$ \\
Mrożony koncentrat soku pomarańczowego & $\mathbf{- 3 , 7 2 0}$ \\
Kauczuk & $\mathbf{- 4 , 9 1 6}$ \\
\hline Uwaga: pogrubiona czcionka oznacza odrzucenie $\mathrm{H}_{0}$
\end{tabular}

Źródło: obliczenia własne.

Tylko dla dwóch towarów (kawa, cukier) otrzymano dodatnią wartość statystyki $K$, co może świadczyć o występowaniu procesu powracania do średniej, zaś dla pozostałych towarów (kakao, bawełna, mrożony koncentrat soku pomarańczowego i kauczuk) można stwierdzić, że w danych przeważają trendy. W przypadku towarów: cukier i bawełna, można przypuszczać, że $R_{t}^{*}$ może być generowany przez biały szum $(|K|<1,96)$.

W kolejnym etapie badań przeprowadzono testy niezależności przyrostów cen. Wyniki testu autokorelacji dla $k=1,2, \ldots, 10$ przedstawiono $\mathrm{w}$ tabeli 3. Analizując je, można zauważyć, że hipotezę zerową $\mathrm{H}_{0}$, mówiącą o tym, że ceny są ze sobą nieskorelowane, należało odrzucić dla autokorelacji rzędu $k=1 \mathrm{w}$ przypadku następujących towarów: kakao, bawełna, mrożony koncentrat soku pomarańczowego oraz kauczuk. Dla autokorelacji rzędu $k=2$ hipotezę zerową należało odrzucić w odniesieniu do kauczuku, zaś dla $k=3 \mathrm{w}$ odniesieniu do kawy i cukru. Przy $k=\{4,10\}$ hipotezę zerową odrzucamy tylko dla kauczuku, zaś przy $k=7$ tylko dla bawełny. Pomimo tego, że w większości przypadków nie było podstaw do odrzucenia hipotezy zerowej, to należy zauważyć, że współczynniki autokorelacji $\hat{\rho}(k)$ są różne od zera. Przyjmują jednak niewielkie wartości. Zatem można przypuszczać, że ceny towarów mogą być skorelowane, ale zbyt słabo, ażeby formułować daleko idące wnioski. Nie można zatem jednoznacznie stwierdzić, że badane szeregi czasowe złożone ze stóp zwrotu badanych towarów składają się z niezależnych zmiennych losowych (zobacz również Jajuga, 2000).

Wyniki przeprowadzonego testu Boxa-Pierce'a (wartości statystyki Q) przedstawiono w tabeli 4. 
Tabela 3. Wartości autokorelacji rzędu k oraz wartości statystyki S dla logarytmicznych stóp zwrotu towarów z grupy soft commodities

Table 3. Values of autocorrelation of order $\mathrm{k}$ and values of S statistics for logarithmic returns of soft commodities

\begin{tabular}{|c|c|c|c|c|c|c|c|}
\hline $\mathrm{k}$ & $\begin{array}{c}\text { Statystyk } \\
\text { a }\end{array}$ & Kawa & Kakao & Cukier & Bawełna & $\begin{array}{c}\text { Mrożony } \\
\text { koncentrat soku } \\
\text { pomarańczoweg } \\
\text { o }\end{array}$ & Kauczuk \\
\hline \multirow{2}{*}{1} & $\operatorname{ro}(1)$ & $-0,0336$ & 0,0464 & $-0,0099$ & 0,1126 & 0,0874 & 0,1233 \\
\hline & $\mathrm{S}$ & $-1,7179$ & 2,3722 & $-0,5035$ & 5,7511 & 4,4626 & 6,2976 \\
\hline \multirow{2}{*}{2} & $\operatorname{ro}(2)$ & 0,0102 & 0,0116 & $-0,0149$ & 0,0182 & $-0,0071$ & 0,0438 \\
\hline & $\mathrm{S}$ & 0,5198 & 0,5925 & $-0,7620$ & 0,9289 & $-0,3623$ & 2,2378 \\
\hline \multirow{2}{*}{3} & $\operatorname{ro}(3)$ & 0,0562 & $-0,0197$ & 0,0391 & $-0,0183$ & 0,0224 & 0,0126 \\
\hline & $\mathrm{S}$ & 2,8685 & $-1,0053$ & 1,9957 & $-0,9335$ & 1,1438 & 0,6454 \\
\hline \multirow{2}{*}{4} & ro(4) & $-0,0172$ & $-0,0315$ & $-0,0222$ & 0,0031 & 0,0051 & 0,0667 \\
\hline & S & $-0,8799$ & $-1,6090$ & $-1,1325$ & 0,1587 & 0,2581 & 3,4090 \\
\hline \multirow{2}{*}{5} & $\operatorname{ro}(5)$ & 0,0060 & 0,0088 & $-0,0360$ & 0,0106 & $-0,0080$ & 0,0216 \\
\hline & $\mathrm{S}$ & 0,3076 & 0,4480 & $-1,8366$ & 0,5431 & $-0,4062$ & 1,1034 \\
\hline \multirow{2}{*}{6} & $\operatorname{ro}(6)$ & $-0,0004$ & 0,0033 & $-0,0059$ & $-0,0262$ & $-0,0039$ & $-0,0305$ \\
\hline & $\mathrm{S}$ & $-0,0214$ & 0,1674 & $-0,3019$ & $-1,3405$ & $-0,2012$ & $-1,5562$ \\
\hline \multirow{2}{*}{7} & $\operatorname{ro}(7)$ & $-0,0060$ & 0,0107 & $-0,0015$ & 0,0452 & $-0,0098$ & 0,0341 \\
\hline & $\mathrm{S}$ & $-0,3048$ & 0,5473 & $-0,0771$ & 2,3112 & $-0,5010$ & 1,7413 \\
\hline \multirow{2}{*}{8} & $\operatorname{ro}(8)$ & 0,0102 & 0,0053 & 0,0044 & $-0,0231$ & $-0,0339$ & 0,0354 \\
\hline & $\mathrm{S}$ & 0,5235 & 0,2690 & 0,2225 & $-1,1777$ & $-1,7308$ & 1,8107 \\
\hline \multirow{2}{*}{9} & $\operatorname{ro}(9)$ & $-0,0243$ & 0,0171 & $-0,0115$ & $-0,0296$ & $-0,0058$ & 0,0131 \\
\hline & $\mathrm{S}$ & $-1,2397$ & 0,8755 & $-0,5895$ & $-1,5118$ & $-0,2964$ & 0,6708 \\
\hline \multirow{2}{*}{10} & $\operatorname{ro}(10)$ & 0,0109 & $-0,0207$ & 0,0103 & $-0,0190$ & 0,0206 & 0,0554 \\
\hline & S & 0,5571 & $-1,0572$ & 0,5243 & $-0,9690$ & 1,0519 & 2,8311 \\
\hline
\end{tabular}

Uwaga: pogrubiona czcionka oznacza odrzucenie $\mathrm{H}_{0}$

Źródło: obliczenia własne.

Tabela 4. Wartości statystyki Q dla logarytmicznych stóp zwrotu towarów z grupy soft commodities Table 4. Values of Q statistics for logarithmic returns of soft commodities

\begin{tabular}{l|ccc}
\hline \multicolumn{1}{c|}{ Q } & 10 & 20 & 30 \\
\hline Kawa & 14,533 & $\mathbf{3 2 , 1 3 2}$ & $\mathbf{6 0 , 4 5 8}$ \\
Kakao & 12,063 & 21,129 & 38,054 \\
Cukier & 10,242 & $\mathbf{3 7 , 0 1 1}$ & 40,108 \\
Bawełna & $\mathbf{4 6 , 8 8 0}$ & $\mathbf{5 6 , 8 3 7}$ & $\mathbf{6 9 , 2 0 1}$ \\
Mrożony koncentrat soku & $\mathbf{2 6 , 0 6 7}$ & $\mathbf{5 4 , 7 9 1}$ & $\mathbf{6 2 , 3 5 0}$ \\
pomarańczowego & $\mathbf{7 5 , 1 2 0}$ & $\mathbf{8 5 , 4 7 6}$ & $\mathbf{9 5 , 8 3 1}$ \\
Kauczuk & &
\end{tabular}

Źródło: obliczenia własne. 
Analizując wyniki, zawarte $\mathrm{w}$ tabeli 4 , można zauważyć, że w przypadku kakao, bawełny, mrożonego koncentratu soku pomarańczowego i kauczuku liczba współczynników autokorelacji, które wzięto pod uwagę, nie miała wpływu na wynik testu. W przypadku bawełny, mrożonego koncentratu soku pomarańczowego i kauczuku wartości statystyki $Q$ wskazują, że na poziomie istotności 0,05 hipotezę zerową $\mathrm{H}_{0}$ należy odrzucić, gdyż wszystkie wartości statystyki $Q$ były większe od wartości krytycznych, co oznacza autokorelację stóp zwrotu tych towarów. Natomiast dla kakao brak podstaw do odrzucenia $\mathrm{H}_{0}$. Q').

W tabeli 5 podano wyniki przeprowadzonego testu Boxa-Ljunga (wartości statystyki

Tabela 5. Wartości statystyki Q’ dla logarytmicznych stóp zwrotu towarów z grupy soft commodities.

Table 5. Values of Q' statistics for logarithmic returns of soft commodities

\begin{tabular}{l|lll}
\hline \multicolumn{1}{c|}{$\mathrm{Q}^{\prime}$} & 10 & 20 & 30 \\
\hline Kawa & 14,542 & $\mathbf{3 2 , 2 5 4}$ & $\mathbf{6 0 , 8 1 0}$ \\
Kakao & 12,070 & 21,182 & 38,262 \\
Cukier & 10,250 & $\mathbf{3 7 , 1 5 8}$ & 40,285 \\
Bawełna & $\mathbf{4 6 , 8 9 4}$ & $\mathbf{5 6 , 9 1 0}$ & $\mathbf{6 9 , 3 8 8}$ \\
Mrożony koncentrat soku & & & \\
pomarańczowego & $\mathbf{2 6 , 0 7 1}$ & $\mathbf{5 4 , 9 2 9}$ & $\mathbf{6 2 , 5 5 8}$ \\
Kauczuk & $\mathbf{7 5 , 1 5 9}$ & $\mathbf{8 5 , 5 7 6}$ & $\mathbf{9 6 , 0 2 5}$ \\
\hline
\end{tabular}

Uwaga: pogrubiona czcionka oznacza odrzucenie $\mathrm{H}_{0}$

Źródło: obliczenia własne.

Analizując wyniki, zawarte $\mathrm{w}$ tabeli 5 , można zauważyć, że ponownie w przypadku kakao, bawełny, koncentratu i kauczuku liczba współczynników autokorelacji, które wzięto pod uwagę, nie miała wpływu na wynik testu. Wyniki testu Boxa-Ljunga okazały się takie same, jak w teście Boxa-Pierce'a. W przypadku bawełny, mrożonego koncentratu soku pomarańczowego i kauczuku wartości statystyki $Q$ ' wskazują, że na poziomie istotności 0,05 hipotezę zerową $\mathrm{H}_{0}$ należy odrzucić, zaś dla kakao brak podstaw do odrzucenia $\mathrm{H}_{0}$. Zatem na podstawie obu przeprowadzonych testów: Boxa-Pierce'a i Boxa-Ljunga $\mathrm{w}$ zasadzie można przypuszczać, że elementy badanych szeregów czasowych złożonych z logarytmicznych przyrostów cen towarów nie są niezależnymi zmiennymi losowymi (oprócz kakao, w przypadku którego nie odrzucono hipotezy zerowej dla żadnego $k$ ).

\section{Podsumowanie}

Celem niniejszej pracy była weryfikacja słabej formy efektywności informacyjnej rynku towarów z grupy „soft commodities”. Są one niezwykle istotne z punktu widzenia międzynarodowej wymiany handlowej, co znajduje odzwierciedlenie w konstrukcji najważniejszych indeksów towarowych. Na przykład, w portfelu Thomson Reuters/Core Commodity Index, uważanego za główny światowy barometr cen towarów, „soft commodities" mają prawie 30-procentowy udział. 
Do najważniejszych towarów z grupy „soft commodities” zalicza się kawę, kakao, cukier, bawełnę, mrożony koncentrat soku pomarańczowego oraz kauczuk. Dzienne notowania tych towarów w okresie od 2 stycznia 2007 do 30 grudnia 2016 roku stanowily podstawę prezentowanych badań, $\mathrm{w}$ ramach których wykonano test serii oraz testy niezależności przyrostów: test autokorelacji oraz testy Boxa-Pierce'a i Boxa-Ljunga. Analizując otrzymane wyniki zauważamy, że tylko rynek cukru można uznać za efektywny informacyjnie $\mathrm{w}$ formie słabej $\mathrm{w}$ badanym okresie. To oznacza, że wykorzystywanie historycznych notowań tego towaru do prognozowania przyszłych poziomów jego ceny nie jest zasadne. Natomiast wszystkie przeprowadzone testy wskazują na nieefektywność rynku kauczuku. Pozostaje to $\mathrm{w}$ zgodzie $\mathrm{z}$ wnioskami, przedstawionymi przez Borowskiego (Borowski, 2015b), który badając notowania kontraktów futures na kauczuk z giełdy Tokyo Commodity Exchange w okresie od 01.12.1981 do 31.03.2015, stwierdził występowanie efektów kalendarzowych (zarówno efektu miesiąca, jak i efektu dnia tygodnia). $\mathrm{W}$ odniesieniu do pozostałych towarów otrzymane przez nas wyniki nie są już tak jednoznaczne. Rodzi to konieczność kontynuacji omawianych badań z wykorzystaniem innych, bardziej zaawansowanych metod.

Niemniej, przedstawione wnioski są ważne zarówno dla podmiotów, poszukujących zabezpieczenia przed ryzykiem zmiany ceny na rynkach „soft commodities”, czyli stosujących tzw. hedging, jak i dla stosujących spekulację. W interesie tych pierwszych leży efektywność rynku, gdyż wtedy bieżące ceny zawsze odzwierciedlają całą dostępną informację i nie muszą już w swoich decyzjach brać pod uwagę historycznych notowań towarów. Natomiast stosujący spekulację są nastawieni na osiąganie ponadprzeciętnych zysków, wynikających z braku efektywności informacyjnej rynku i występowania pewnych anomalii. Koncentrują się więc oni na analizie historycznych notowań w celu znalezienia strategii inwestycyjnych, które przyniosą spodziewane zyski. Również instytucje, które nadzorują funkcjonowanie rynków ,soft commodities” powinny być zainteresowane kwestią efektywności informacyjnej, ponieważ jej brak utrudnia monitorowanie rynku i wykrywanie ewentualnych manipulacji. Więcej na temat tych mechanizmów pisze Otto (Otto, 2010).

\section{Bibliografia}

Algieri, B., Kalkhul, M. (2014). Back to the Futures: An Assessment of Commodity Market Efficiency and Forecast Error Drivers. ZEF-Discussion Papers on Development Policy, 195, Center for Development Research, Bonn. Ali, J., Gupta, K. (2011). Efficiency in Agricultural Commodity Futures Markets in India: Evidence from Cointegration and Causality Tests. Agricultural Finance Review, 71, 162-178.

Alvarez-Ramirez, J., Alvarez, J., Rodriguez, E. (2008). Short-term Predictability of Crude Oil Markets: A Detrended Fluctuation Analisis Approach. Energy Economics, 30, 2645-2656.

Aulton, A., Ennew, C., Rayner, A. (1997). Efficiency Tests of Futures Markets for UK Agricultural Commodities. Journal of Agricultural Economics, 48, 408-423.

Bigman, D., Goldfarb, D., Schechtman, E. (1983). Futures Markets Efficiency and the Time Content of the Information Sets. Journal of Futures Markets, 3, 321-334.

Borowski, K. (2015a). Analysis of Selected Seasonality Effects in Markets of Frozen Concentrated Orange Juice Future Contracts. Journal of Capital Market and Behavioral Finance, 1(1), 7-30.

Borowski, K. (2015b). Analysis of Selected Seasonality Effects in Markets of Rubber Future Contracts Quoted on Tokyo Commodity Exchange. International Journal on Economics and Finance, 7(9), 15-30.

Buczek, S. B. (2006). Efektywność informacyjna rynków akcji, Teoria a rzeczywistość, Szkoła Główna Handlowa w Warszawie - Oficyna Wydawnicza, Warszawa 2006

Canarella, G., Pollard, S. (1985). Efficiency of Commodity Futures: A Vector Autoregression Analysis. Journal of Futures Markets, 5, 57-76. 
Charles, A., Darné, O. (2009). The Efficiency of the Crude Oil Market: Evidence from Variance Ratio Tests. Energy Policy, 37, 4267-4272.

Czekaj, J., Woś, M., Żarnowski, J. (2001). Efektywność giełdowego rynku akcji w Polsce. Z perspektywy dziesięciolecia. Wydawnictwo Naukowe PWN, Warszawa.

Fabozzi, J., Füss, R., Kaiser, D.G. (2008). A Primer on Commodity Investing. The Handbook of Commodity Investing. John Wiley \& Sons Inc., Hoboken, New Jersey, 3-37.

Fama, E.F. (1970). Efficient Capital Markets: A Review of Theory and Empirical Work. Journal of Finance, 25, $383-417$.

Gjolberg, O. (1985). Is the Spot Market for Oil Products Efficient? Some Rotterdam Evidence. Energy Economics 7(4), 231-236.

Gordon J. (1985). The distribution in daily changes in commodity futures prices. Technical Bulletin, 1702, ERS USDA.

Górska, A., Krawiec, M. (2016). The Analysis of Weak-form Efficiency in the Market of Crude Oil. European Journal of Economics and Business Studies, 5(1), 101-112.

Jajuga, K. [red.] (2000). Metody ekonometryczne i statystyczne w analizie rynku kapitałowego. Wydawnictwo Akademii Ekonomicznej im. Oskara Langego we Wrocławiu, Wrocław.

Kristoufek, L., Vosvrda, M. (2014). Commodity Futures and Market Efficiency. Energy Economics, 42, 50-57.

Lokare, S. (2007). Commodity Derivatives and Price Risk Management: An Empirical Anecdote from India. Reserve Bank of India Occasional Papers, 28.

McKenzie, A., Holt, M. (2002). Market Efficiency in Agricultural Futures Markets. Applied Economics, 34, 15191532.

Osińska, M. (2006). Ekonometria finansowa. PWE, Warszawa.

Otto, S. (2010). Does the London Metal Exchange Follow a Random Walk? Evidence from the Predictability of Futures Prices. Open Economic Journal, 3, 25-42.

Panas, E. (1991). A Weak Form Evaluation of the Efficiency of the Rotterdam and Italian Oil Spot Markets. Evidences from Informational Entropy Analysis. Energy Policy, 41, 365-373.

Papla, D. (2003). Związki pomiędzy zmianami poziomu efektywności informacyjnej i wielkością spółek na GPW w Warszawie. Dynamiczne Modele Ekonometryczne, VIII Ogólnopolskie Seminarium Naukowe, Wydawnictwo Uniwersytetu Mikołaja Kopernika w Toruniu, str. 283 - 292, Toruń.

Sabuhoro, J., Larue, B. (1997). The Market Efficiency Hypothesis: The Case of Coffee and Cocoa Futures. Agricultural Economics, 16, 171-184.

Taylor, S. J. (1986). Modeling Financial Time Series. New York, NY: John Wiley and Sons.

Tomaszewski, J. (2013). Instrumenty towarowe jako forma inwestycji alternatywnych w portfelach inwestorów finansowych. Oficyna Wydawnicza SGH w Warszawie, Warszawa.

Wang, H., Ke, B. (2005). Efficiency Tests of Agricultural Commodity Futures Markets in China. Australian Journal of Agricultural and Resource Economics, 49, 125-141.

Witkowska D., Matuszewska A., Kompa K. (2008). Wprowadzenie do ekonometrii dynamicznej i finansowej. Wydawnictwo SGGW, Warszawa.

www.bloomberg.com

Zahng, B., Li, X., He, F. (2014). Testing the Evolution of Crude Oil Market Efficiency: Data Have the Conn. Energy Policy, 68, 39-52.

Zawojska, A. (2011). Czy spekulacje finansowe wpływają na międzynarodowe ceny towarów rolnożywnościowych? Zeszyty Naukowe SGGWw Warszawie, Problemy Rolnictwa Światowego, 11(1), 177-192. 